\title{
2008 Finansal Krizi Sonrası Türkiye'de Konut Fiyatlarının Belirleyicilerine Yönelik Analiz
}

\author{
İlkay DİLBER ${ }^{1}$, Yasin SERTKAYA ${ }^{2 a}$ \\ ${ }^{1}$ Doç. Dr., Celal Bayar Üniversitesi, İ̈BF, İktisat Bölümü - Manisa / Türkiye. \\ ${ }^{2}$ Celal Bayar Üniversitesi, Sosyal Bilimler Enstitüsü, İktisat Bölümü - Manisa / Türkiye.

Konut bir yandan bireylerin barınma gibi temel sosyal gereksinimlerini karşılarken, diğer taraftan alternatif bir servet biriktirme aracı olma özelliği ile ekonomik açıdan da çok önemlidir. Bu özelliğinden dolayı konutun uzun dönem net değeri ve nakit getirisi, yatırım açısından büyük önem kazanmaktadır. Konut fiyatları, binanın inşaat malzemesinden coğrafi konumuna ve yaşına (yıpranma oranını) kadar pek çok faktörün yanı sıra, makroekonomik değişkenlerden de etkilenmektedir. 2008 yılında, ABD piyasalarında görülen ve tüm dünyayı etkileyen finansal kriz, etkilerini tüm piyasalarda olduğu gibi konut piyasası ve inşaat sektöründe de göstermiştir. Türkiye Ekonomisi'nde de bu krizin etkileri görülmüş ve ekonomik büyüme 2009 yılında negatif olmuştur.

$\mathrm{Bu}$ çalışmada, Türkiye'de konut fiyatlarını etkileyen makroekonomik değişkenler nedensellik ilişkisi vasıtası ile sınanmaktadır. Bu amaçla, 2008-2014 dönemine ait çeyrek yıllık veriler kullanarak, Türkiye'deki konut fiyat endeksini etkileyen değişkenler analiz edilmiştir. Yapılan analizler sonucunda, konut fiyat endeksi ile döviz kuru arasında çift yönlü, faiz oranı ve enflasyon oranı arasında tek yönlü bir ilişki tespit edilmiştir.

\section{Anahtar Kelimeler}

Konut Fiyat Endeksi, Enflasyon, Faiz Oranları

a Sorumlu Yazar/Correspoding Author: Celal Bayar Üniversitesi, Sosyal Bilimler Enstitüsü, Muradiye Kampüsü, 45140, Yunusemre / Manisa / Türkiye.

e-posta: yasinsertkaya_1987@hotmail.com 


\section{An Analysis for the Determinants of Housing Prices in Turkey after the 2008 Financial Crisis}

\section{Abstract}

While housing, on one hand, meets the basic social needs of individuals like shelter, on the other hand, with its being an alternative wealth accumulation means, it is very important economically. Because of this feature, it has gained great importance in terms of investment due to its long-term net value and cash return. As well as by the building's construction materials, geographic location, age and many other factors, housing prices are also affected by macro-economic variables. Emerged in 2008, the financial crisis whose effects can be seen in the USA markets and which affected all over the world has shown its effects in the housing market and construction as shown in all the markets. Turkey has also seen the effects of this crisis and the economic growth has been negative in 2009.

In this study, the macroeconomic variables that affect housing prices in Turkey are tested by means of a causal relationship. For this purpose, by using quarterly data belonging to the period 2008-2014, the variables that have affected housing prices index in Turkey have been analysed. As a result of the analyses, a bidirectional relationship has been detected between housing prices index and currency and a unidirectional relationship has been detected between interest rates and inflation.

\section{Keywords}

House Price Index, Inflation, Interest Rates

\section{GÍRIŞ}

ABD'de 2008 y1lında türev piyasalar yüzünden yaşanan, 2008 finansal krizinin etkileri en çok konut piyasasında hissedilmiştir. ABD'de ortaya çıkan krizin temel nedeni, 2000'li yıllarda konut fiyatlarında görülen artışın konut piyasalarında olumlu bir etki yaratması bunun sonucu olarak da bankaların konut alacak kişilere daha kolay kredi vermesine yol açmasıdır. Bu durum yatırım amaçlı konut alanları harekete geçirmiş ve konut fiyatlarında bir yükselmeye yol açmıştır. Daha sonra fiyatların da en yüksek seviyeye ulaşması ile konutlara olan talebin azalması ve alınan kredilerin geri ödenememesi ile birleşince sistem çökmüştür. Evlerin çoğu satılamamış, fiyatlarında düşüş yaşanmıştır. Ayrıca çoğu finans şirketi de iflas etmiştir. ABD'de başlayıp AB ülkelerine yayılan finansal kriz birçok Avrupa 
ülkesini iflasın eşiğine getirmiştir. Çoğu Avrupa ülkesi mali anlamda güçlendirici planlar uygulamıştır.

Çalışma, konut fiyat endeksi konusundaki mevcut istatistiklerin derlenip bir bütün olarak değerlendirilmesi ve bu doğrultu da Türkiye'deki konut fiyatlarını etkileyen değişkenlerin tespit edilmesi amacı ile yapılmıştır. Bu doğrultuda hazırlanan çalışmanın temel amacı, 2008-2014 yılları arasındaki dönemde konut fiyat endeksi, enflasyon oranı, reel efektif döviz kuru ve konut kredi faiz oranları arasındaki ilişkinin geçerliliğini sınamak ve böylelikle konu ile ilgili literatüre yeni bir çalışma kazandırmaktır. Çalışmanın birinci bölümünde giriş bölümü yer almaktadır. İkinci bölümde konuyla ilgili literatür araştırması yer almaktadır. Üçüncü bölümde veri seti ve uygulanan ekonometrik yöntem kısmı ele alınmıştır. Ekonometrik analizlerin yer aldığı dördüncü bölümde çalışmada kullanılan veriler ile uygulanan analizlerden elde edilen sonuçlar açıklanmaktadır. Beşinci bölümde ise sonuç bölümü yer almaktadır.

\section{LITERATÜR İNCELEMESI}

Ulusal ve uluslar arası literatür incelendiğinde konut satışları ve konut fiyatlarını etkileyen birçok faktörden söz edilmektedir. Konut satışları ve konut fiyatlarının temel belirleyicilerinin incelendiği çalımalar ve bulguları tablo 1'de özetlenmektedir.

Tablo 1. Literatür Araştırması

\begin{tabular}{|c|c|c|}
\hline Çalışma & Yazarlar (Yıl) & Sonuç ve Açıklamalar \\
\hline $\begin{array}{l}\text { Effective Housing Demand } \\
\text { in Mumbai (Bombay) } \\
\text { Metropolitan Region, } \\
\text { Urban Studies }\end{array}$ & Tiwari vd. (1999) & $\begin{array}{l}\text { Çalışmada, Hindistan'ın Mumbai kentinde konut } \\
\text { talebi ile gelir arasındaki ilişki araştırılmaktadır. } \\
\text { Yatay kesit verileri kullanılarak yapılan analiz } \\
\text { sonucunda, konut talebi ile gelir arasındaki esneklik } \\
\text { negatif çıkmıştır. }\end{array}$ \\
\hline $\begin{array}{l}\text { An Application of the } \\
\text { Hedonic Price Model with } \\
\text { Uncertain Attribute the } \\
\text { Case of the People's } \\
\text { Republic of China }\end{array}$ & Yang (2001) & $\begin{array}{l}\text { Çalışmada Çin'deki konut fiyatları ile fiziksel yapı, } \\
\text { konum, çevre ve yapı kalitesi arasındaki ilişki analiz } \\
\text { edilmiştir. Analiz sonucunda ele alınan değişkenlerin } \\
\text { konut fiyatları üzerinde olumlu bir etkiye sahip } \\
\text { olduğu görülmektedir. }\end{array}$ \\
\hline $\begin{array}{l}\text { İzmir İlinde Emlak } \\
\text { Fiyatlarına Etki Eden } \\
\text { Faktörler-Hedonik } \\
\text { Yaklaşım }\end{array}$ & Üçdoğruk (2001) & $\begin{array}{l}\text { Çalışma, İzmir ilindeki tüm ilçelerde konut } \\
\text { fiyatlarına etki eden değişkenleri tespit etmek amacı } \\
\text { ile gerçekleştirilmiştir. Oluşturulan modeller } \\
\text { sonucunda kat kaloriferi, merkezi kalorifer ve } \\
\text { jeotermal enerji bulunan konutların fiyatlarının, soba } \\
\text { ile isınma sistemi bulunan konutların fiyatlarından } \\
\text { daha yüksek olduğu sonucuna ulaşılmıştır. Ayrıca } \\
\text { parkenin bulunması, çatı yalıtımı ve hazır mutfak } \\
\text { gibi unsurlarında fiyatı etkilediği tespit edilmiştir. }\end{array}$ \\
\hline $\begin{array}{l}\text { What Drives Housing Price } \\
\text { Dynamics: Cross-Country } \\
\text { Evidence, }\end{array}$ & $\begin{array}{l}\text { Tsatsaronis ve } \\
\text { Zhu (2004) }\end{array}$ & $\begin{array}{l}\text { Çalışmada, para arzında görülen değişimlerin konut } \\
\text { fiyatları üzerinde negatif bir etkiye sahip olduğu } \\
\text { sonucuna varılmıştır. }\end{array}$ \\
\hline $\begin{array}{l}\text { Hedonic Price Analysis of } \\
\text { Urban Housing: An }\end{array}$ & Wen vd. (2005) & $\begin{array}{l}\text { Çalışmada Çin'in Hang Zhou kentinde konut } \\
\text { satışlarını etkileyen değişkenleri tespit etmektedirler. } \\
\text { Bu bağlamda konutun yaşı, konumu, sağlık, banka, }\end{array}$ \\
\hline
\end{tabular}




\begin{tabular}{|c|c|c|}
\hline $\begin{array}{l}\text { Empirical Research on } \\
\text { Hangzhou. }\end{array}$ & & $\begin{array}{l}\text { postane okul gibi kuruluşlara olan uzaklığı ve } \\
\text { okullara olan uzaklığının, konut satış fiyatlarını } \\
\text { etkilemediği sonucuna ulașılmıștır. }\end{array}$ \\
\hline $\begin{array}{l}\text { İzmir Metrosunun Konut } \\
\text { Fiyatları Üzerindeki } \\
\text { Etkilerinin Hedonik Fiyat } \\
\text { Yöntemi ile Modellenmesi } \\
\end{array}$ & $\begin{array}{c}\text { Yankaya ve Çelik } \\
\text { (2005) }\end{array}$ & $\begin{array}{l}\text { Çalışmada İzmir metrosunun konut fiyatları } \\
\text { üzerindeki etkisi araştırılmıştır. Uygulanan hedonik } \\
\text { model sonuçları metroya olan yakınlığın konut } \\
\text { fiyatlarını artırdığını göstermektedir. }\end{array}$ \\
\hline $\begin{array}{l}\text { Estimating Hedonic } \\
\text { Demand Parameters in } \\
\text { Real Estate Market: The } \\
\text { Case of Muğla }\end{array}$ & Kesbiç vd. (2007) & $\begin{array}{l}\text { Çalış̧ma Muğla ilinde konut fiyatlarına etki eden } \\
\text { değişkenleri belirlenmektedir. Elde edilen bulgular } \\
\text { konutun büyüklüğ̈u, merkezi sistemli ısıtma olması, } \\
\text { güneş enerjisi, panjur, hazır mutfak, asansör sayısı, } \\
\text { konutun güney cephede bulunması, şehir merkezine } \\
\text { olan yakınlığı, banyo sayısı gibi özelliklerin konut } \\
\text { fiyatını etkilediğini göstermektedir. }\end{array}$ \\
\hline $\begin{array}{l}\text { Türkiye'de Konut Fiyatları } \\
\text { ile Makro Ekonomik } \\
\text { Değişkenler Arasındaki } \\
\text { İlişkinin Araştırılması }\end{array}$ & Badurlar (2008) & $\begin{array}{l}\text { Çalışmada 1990-2006 dönemi için Türkiye'de } \\
\text { makroekonomik değişkenlerin konut fiyatları } \\
\text { üzerindeki etkisi ele alınmıştır. Uygulanan analizler } \\
\text { sonucunda konut satışları ile döviz kuru arasında çift } \\
\text { yönlü bir nedenselliğe rastlanılmıştır. }\end{array}$ \\
\hline $\begin{array}{l}\text { Spatial Hedonic Models of } \\
\text { Airport Noise, Proximity, } \\
\text { and Housing Prices }\end{array}$ & $\begin{array}{c}\text { Cohen ve } \\
\text { Coughlin (2008) }\end{array}$ & $\begin{array}{l}\text { Çalışmada Atalanta hava alanına yakın konutların } \\
\text { fiyatlarına hava alnından kaynaklanan gürültünün } \\
\text { etkisi araştırılmış̦tır. Uygulanan analizler sonucunda } \\
\text { gürülttüden uzak olan konutların, nispi olarak yüzde } \\
\text { yirmi daha değerli olduğu tespit edilmiştir. }\end{array}$ \\
\hline $\begin{array}{l}\text { Türkiye'de Konut } \\
\text { Piyasasının Belirleyicileri: } \\
\text { Ampirik Bir Uygulama }\end{array}$ & $\begin{array}{l}\text { Öztrük ve Fitöz } \\
\text { (2009) }\end{array}$ & $\begin{array}{l}\text { Çalışmada konut arzı ve talebinin belirleyicileri } \\
\text { tespit edilmiştir. Ulaşılan sonuçlara göre, kişi başına } \\
\text { milli gelir, konut fiyatları, faiz oranları ve konut } \\
\text { talebi arasında doğru yönlü bir ilişki bulunmaktadır. } \\
\text { Ayrıca kişi başına milli gelir, konut fiyatları ve para } \\
\text { arzı ile konut arzı arasında aynı yönde bir ilişki } \\
\text { olduğu saptanmıştır. }\end{array}$ \\
\hline $\begin{array}{l}\text { Macroeconomic } \\
\text { determinanats of } \\
\text { international } \\
\text { housing markets. Journal } \\
\text { of Housing Economics } \\
\end{array}$ & $\begin{array}{l}\text { Adams ve Füss } \\
\text { (2010) }\end{array}$ & $\begin{array}{l}\text { Çalışmada } 15 \text { OECD ülkesi için konut fiyatları ile } \\
\text { reel GSYİH, istihdam düzeyi, sanayi üretimi ve faiz } \\
\text { oranları arasındaki ilişsi ele alınmıştır. Çalışmanın } \\
\text { sonucunda ele alınan değişkenlerin konut fiyatlarını } \\
\text { olumlu yönde etkilediği sonucuna ulaşılmaktadır. }\end{array}$ \\
\hline $\begin{array}{l}\text { International house price } \\
\text { and macroeconomic } \\
\text { fluctuations }\end{array}$ & $\begin{array}{c}\text { Beltratti ve } \\
\text { Morana (2010) }\end{array}$ & $\begin{array}{l}\text { Çalışmada, G7 ülkeleri için konut fiyatlarında } \\
\text { görülen artışın yaşanan makroekonomik şoklar ile } \\
\text { ilgili olduğu sonucuna ulaşılmıştır. }\end{array}$ \\
\hline $\begin{array}{l}\text { Boom and Busts in } \\
\text { Housing Markets: } \\
\text { Determinants and } \\
\text { Implications }\end{array}$ & $\begin{array}{l}\text { Agnello ve } \\
\text { Schuknecht } \\
\quad(2011)\end{array}$ & $\begin{array}{l}\text { Çalışmada ele alınan } 18 \text { gelişmiş ülke için 1980-2007 } \\
\text { ylları arasında oluşan konut arzı fazlasının, konut } \\
\text { faiz oranlarının düşük olması ve kredi miktarlarının } \\
\text { fazla olmasından dolayı kaynaklandığı sonucuna } \\
\text { ulaşılmıştır. }\end{array}$ \\
\hline $\begin{array}{l}\text { Housing market and } \\
\text { economic growth relation: } \\
\text { time series analysis over } \\
\text { Turkey }(2000-2012)\end{array}$ & Karg1 (2013) & $\begin{array}{l}\text { Çalışmada yapılan analizler sonucunda kredi hacmi } \\
\text { genişlemesi ve konut harcamaları ile ekonomik } \\
\text { büyüme değişkenleri arasında bir nedensellik } \\
\text { ilişkisine rastlanılmıştır. }\end{array}$ \\
\hline
\end{tabular}

Çalışmada 75 ülkenin konut fiyat endeksi verileri ile makroekonomik değişkenler arasındaki ilişki panel

Konut Fiyatları ve Makroekonomik Faktörler Çankaya (2013) veri analizi yardımı ile incelenmiştir. Çalışmanın Arası İlişkiye Global Bakış soncunda kredi faiz oranı, kişisel harcanabilir gelir ve büyüme arasında doğru yönlü bir ilişkiye rastlanırken, istihdam ve nüfus verileri ile ters yönlü bir ilişki bulunmuştur. 


\begin{tabular}{|c|c|c|}
\hline $\begin{array}{l}\text { Konut Sahipliğinin } \\
\text { Belirleyicileri: } \\
\text { Hane halk1 Reisleri } \\
\text { Üzerine Bir Uygulama }\end{array}$ & Tatlı (2013) & $\begin{array}{l}\text { Çalışmada Malatya'daki hane halkı reislerinin konut } \\
\text { sahipliğini etkileyen değişkenler araştırılmıştır. } \\
\text { Uygulanan logit model sonucunda, hane halkı } \\
\text { reisinin evli olması, gelir durumu ve yaş durumu, } \\
\text { konut sahipliğini olumlu yönde etkilediği sonucuna } \\
\text { ulaşılmıştır. }\end{array}$ \\
\hline $\begin{array}{l}\text { Toplu Konut Projelerinde } \\
\text { Maliyetlerin Regresyon } \\
\text { Metodu ile İncelenmesi }\end{array}$ & $\begin{array}{l}\text { Uğur ve Sivri } \\
\text { (2014) }\end{array}$ & $\begin{array}{l}\text { Çalışmada uygulanan çoklu regresyon analizi } \\
\text { sonucunda toplam daire sayısı ile blok sayısı, toplam } \\
\text { alan ve blok sayısı, toplam alan ile toplam daire } \\
\text { sayıs değişkenleri arasında yüksek korelasyon } \\
\text { olduğu sonucuna ulaşı1mıștır. }\end{array}$ \\
\hline $\begin{array}{l}\text { Konut Sektöründe } \\
\text { Kapitalizasyon Oranlarını } \\
\text { Belirleyen Faktörler: } \\
\text { Türkiye için Bir Mikro } \\
\text { Veri Analizi }\end{array}$ & $\begin{array}{l}\text { Pinar ve Demir } \\
\text { (2014) }\end{array}$ & $\begin{array}{l}\text { Çalışmada konutların büyüklüğü, merkeze yakınlığı } \\
\text { gibi nedenlerin konutların kapitalizasyonu üzerinde } \\
\text { etkili olduğu görülmüştür. Ayrıca ikinci el } \\
\text { konutların, kapitalizasyon oranlarının yeni } \\
\text { konutların kapitalizasyon oranlarından daha yüksek } \\
\text { çıkmıştır. }\end{array}$ \\
\hline $\begin{array}{l}\text { Türkiye'nin Konut } \\
\text { Talebinin Analizi: } \\
\text { 1970-2011 }\end{array}$ & $\begin{array}{l}\text { Lebe ve Akbaş } \\
\text { (2014) }\end{array}$ & $\begin{array}{l}\text { Çalışmada, Türkiye'de konut talebini kısa ve uzun } \\
\text { dönemde etkileyen değişkenleri analiz etmişlerdir. } \\
\text { Uygulanan vektör hata düzeltme modeli ve } \\
\text { eşbütünleşme analizi sonucunda, kişi başına gelir, } \\
\text { medeni durum ve sanayileşme ile konut talebi } \\
\text { arasında pozitif yönde; konut fiyatları, faiz ve tarım } \\
\text { sektöründe istihdam arasında ise negatif yönde bir } \\
\text { ilişkiye rastlanmıştır. }\end{array}$ \\
\hline
\end{tabular}

\section{VERİ SETİ VE UYGULANAN EKONOMETRİK YÖNTEM}

Bu çalışmada 2008-2014 yılları arasındaki üç aylık zaman serisi verileri kullanılarak, Konut Fiyat Endeksi, Enflasyon Oranı, Reel Efektif Döviz Kuru Oranı ve Konut Kredisi Faiz Oranları arasındaki ilişkiler incelenmektedir. Çalışmada kullanılan verilerden Konut Fiyat Endeksi, Enflasyon Oranı, Reel Efektif Döviz kuru Oranı ve Konut Kredisi Faiz Oranları Merkez Bankası EVDS (Elektronik Veri Dağıtım Sistemi)'den elde edilmiştir. Analizlerde kullanılan LNKFE, LNENF ve LNDKR, LNKKFO kisaltma ifadeleri sirasiyla Konut Fiyat Endeksi, Enflasyon Oranı, Reel Efektif Döviz kuru ve Konut Kredi Faiz Oranlarının doğal logaritmaları alınmış hallerini temsil etmektedir. Bu verilerin zaman içindeki değişimleri Şekil 1'de görülmektedir. Çalışmada kullanılan verilerin tahmini E-Views 9 programı kullanılarak elde edilmiştir.

Konut Fiyat Endeksi, Enflasyon Oranı, Reel Efektif Döviz kuru ve Konut Kredisi Faiz Oranları değişkenleri mevsimsel özellik gösterdiğinden dolayı öncelikle bu sorunun ortadan kaldırılması gerekmektedir. Bu nedenle ilk adımda değişkenler Eviews-9.0 paket programında Tramo/Seats süreci işletilerek mevsimsellikten arındırılmıştır. Serilerin mevsimsellikten arındırıldıktan sonraki grafikleri Şekil 1'de verilmiş̧ir. 
Şekil 1. Modelde yer alan serilerin grafiği

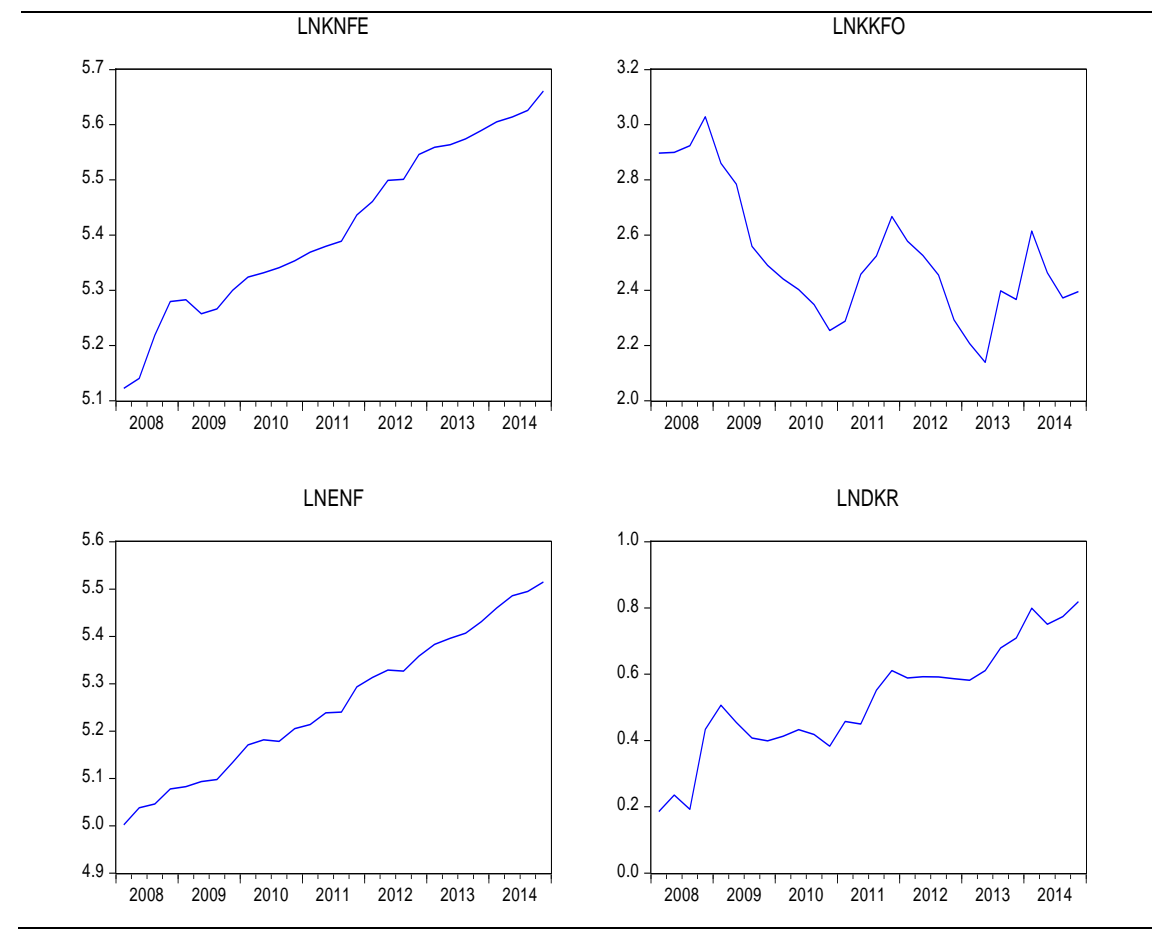

2008-2014 arası 3 aylık konut fiyat endeksi, reel efektif döviz kuru, enflasyon oranı ve konut kredi faiz oranı değerlerinin yer aldığı Şekil 1 incelendiğinde, konut fiyat endeksi, enflasyon, reel efektif döviz kuru serisinin 2008 yılından 2014 y1lına kadar istikrarlı bir şekilde arttığı ve 2014 yılında en yüksek değere ulaştığı görülmektedir. Konut kredi faiz oranı ise diğer değişkenlerin bu durumuna karşılık zit yönde bir durum göstermektedir. 2013 yılına kadar azalma eğilimde olan seri daha sonraki yıllarda artış göstermiştir. En yüksek değeri ise 2014 yılının ilk döneminde görülmektedir.

Çalışmanın ekonometrik analiz kısmında ilk olarak serilerin durağanlıkları ve durağan iseler hangi düzeyde durağan oldukları tespit edilmiştir. Zaman serilerinin durağan halde olması; zaman içinde varyans ve ortalamada değişim yaşanmadan, gecikmeli iki zaman periyodunda yer alan değişkenlerin kovaryansının değişkenler arasındaki gecikmeye dayanarak zamana bağımlı durumda olmamasıdır (Gujarati, 1995: 712). Zaman serisi analizlerinde değişkenlerin durağan halde olması, modelde sahte regresyon sorunuyla karşılaşılmasının önüne geçmektedir. Durağanlığı sağlanan serilerin zaman içerisinde ortalaması, varyansı ve kovaryansında herhangi bir farklılık görülmez ancak durağanlığı sağlanamayan değişkenlerde $\mathrm{t}, \mathrm{Z}$ ve $\mathrm{F}$ dağılımları önemini yitirmektedir. Bu yüzden birçok standart hipotez geçersiz hale gelmektedir (Granger ve Newbold, 1974: 111-120). $\mathrm{Bu}$ çalışmada değişkenlere ait zaman serilerinin durağanlık sınaması, 
Genişletilmiş Dickey-Fuller (ADF) ve Phillips-Perron (PP) Birim Kök testleri kullanılarak gerçekleştirilmiştir.

Durağanlık testlerinin ardından çalışmada değişkenler arasındaki uzun dönemli bir ilişkinin varlığı eş bütünleşme analizi yardımıyla sınanmaktadır

Çalışmada seriler arasında uzun dönem ilişkinin varlığı ve eş bütünleşik vektörlerin sayısının belirlenmesi için, Johansen ve Juselius tarafından geliştirilen çoklu eş bütünleşme testi kullanılmıştır. Bunun için iz (trace) ve maximum özdeğer (eigenvalue) test istatistiği kullanılmaktadır. Her iki testte de kullanılan kritik değerler Johansen ve Juselius tarafindan oluşturulmuştur.

İktisadi ilişkiler arasındaki etkileşimin karmaşıklığı ve çok yönlülüğü, eş anlı denklem sistemlerinin kullanılmasını zorunlu hale getirmektedir. Ayrıca iktisadi parametreler arasındaki karşılıklı etkileşimin doğal bir sonucu olarak ortaya çıkan bağımlı ve bağımsız değişkenin tayini aşamasında karşılaşılan güçlükler, analizin tutarlılığını da önemli ölçüde etkilemektedir. Bu sebeple eş anlı denklem sistemlerinde, belirlenme problemini aşabilmek için bazen yapısal model üzerinde bazı kısıtlamalar yapılması gerekmektedir (Darnell, 1990: 114 -116).

Eşanlı denklem sistemlerinde ortaya çıkan karmaşık tablo sorununun çözümünü sağlayan Vektör Otoregresif Modeller (VAR) ile bu sorun giderilebilmektedir. VAR modelleri ile yapısal modelde bir sınırlamaya gidilmediği için zaman serilerinde tercih edilmektedir (Keating, 1990: 453-454). VAR Model rastgele bir iktisat teorisini baz alarak, değişkenler arasında içsellik ve dışsallık ayrımı yapmamasından dolayı eşanlı denklem sistemlerinden farklı kılınmaktadır. Bunun yanı sıra VAR modeller, bağımlı değişkenlerin gecikmeli değerlere sahip olmasından dolayı geleceğe yönelik kuvvetli öngörülerde bulunmayı sağlamaktadır (Kumar vd., 1995: 365).

VAR model kullanımının altında yatan asıl sebep, hem değişkenler arasındaki tek yönlü ilişkiyi belirlemek hem de değişkenler arasındaki ileriye ve geriye yönelik ilişkiyi tespit etmektir (Kearney ve Monadjemi, 1990: 197-217). Çalışmada kullanılacak olan yöntem Vektör Otoregresif (VAR) Model'dir. İki değişkenli VAR Model, standart şekilde aşağıdaki gibi ifade edilebilmektedir.

$$
\begin{aligned}
& \mathrm{y}_{\mathrm{t}}=\mathrm{a}_{1}+\Sigma \mathrm{b}_{1} \mathrm{i} \mathrm{y}_{\mathrm{t}-\mathrm{i}}+\Sigma \mathrm{b}_{2} \mathrm{i} \mathrm{X}_{\mathrm{t}-\mathrm{i}}+\mathrm{v}_{1} \mathrm{t} \\
& \mathrm{x}_{\mathrm{t}}=\mathrm{c}_{1}+\Sigma \mathrm{d}_{1} \mathrm{i} \mathrm{y}_{\mathrm{t}-\mathrm{i}}+\Sigma \mathrm{d}_{2} \mathrm{i} \mathrm{X}_{\mathrm{t}-\mathrm{i}}+\mathrm{v}_{2} \mathrm{t}
\end{aligned}
$$

1 ve 2 numaralı modelde $p$ gecikmelerin uzunluğunu, v ortalaması sıfir, kendi gecikmeli değerleriyle olan kovaryansları sıfır ve varyansları sabit, normal dağılıma sahip rassal hata terimlerini göstermektedir (Özgen ve Güloğlu, 2004: 96-98).

\section{EKONOMETRİK ANALİZ}

Değişkenler arasındaki ilişkinin yönü ve derecesini saptayabilmek amaciyla kullanılan VAR Analizini gerçekleştirmeden önce ilk olarak serilerin 
durağanlıkları Genişletilmiş Dickey Fuller (ADF) ve Phillips-Perron (PP) testleri aracılığı ile belirlenmiştir. ADF ve PP Birim kök testlerine ilişkin boş ve alternatif hipotezler şöyle oluşturulmaktadır:

$\mathrm{H}_{0}$ : Seriler durağan değildir (birim kök içermektedir).

$\mathrm{H}_{1}$ : Seriler durağandır (birim kök içermemektedir).

Tablo 2. ADF ve PP Birim Kök Testi Sonuçları

\begin{tabular}{ccccc}
\hline Değişkenler & $\begin{array}{c}\text { ADF Testi } \\
\text { (sabit) }\end{array}$ & $\begin{array}{c}\text { ADF Testi } \\
\text { (trend ve sabit) }\end{array}$ & $\begin{array}{c}\text { PP Testi } \\
\text { (sabit) }\end{array}$ & $\begin{array}{c}\text { PP Testi } \\
\text { (trend ve sabit) }\end{array}$ \\
\hline \multicolumn{5}{c}{ Düzey Değeri } \\
\hline LNKNFE & $0.77(1)$ & $-3.34(0)$ & $-1.17(3)$ & $-4.18(4)$ \\
LNENF & $1.38(0)$ & $-3.79(2)$ & $0.12(0)$ & $-3.83(2)$ \\
LNDKR & $-1.22(1)$ & $-2.91(0)$ & $-1.15(1)$ & $-2.99(1)$ \\
LNKKFO & $-2.77(1)$ & $-3.12(3)$ & $-1.90(4)$ & $-1.98(1)$ \\
\hline \multicolumn{6}{c}{ Birinci Farklar } \\
\hline LNKNFE & $-3.73(2)^{* *}$ & $-3.83(2)^{* *}$ & $-9.21(7)^{* * *}$ & $-8.48(9)^{* * *}$ \\
LNENF & $-6.41(4)^{* * *}$ & $-4.61(4)^{* * *}$ & $-10.2(3)^{* * *}$ & $-15.06(8)^{* * *}$ \\
LNDKR & $-5.20(1)^{* * *}$ & $-5.08(1)^{* * *}$ & $-5.40(2)^{* * *}$ & $-5.24(6)^{* * *}$ \\
LNKKFO & $-4.59(5)^{* * *}$ & $-4.60(5)^{* * *}$ & $-4.63(8)^{* * *}$ & $-4.63(8)^{* * *}$ \\
\hline
\end{tabular}

Not: ADF ve PP için kritik değerler MacKinnon (1996) tarafindan elde edilmiştir. Parantez içerisindeki değerler gecikme uzunluklarını ifade etmektedir. Gecikme uzunluğu minimum Schwarz bilgi kriteri dikkate alınarak belirlenmiştir. $* * * \mathrm{p}<.01,{ }^{*} \mathrm{p}<.05,{ }^{*} \mathrm{p}<.10$

Tablo 2'de yer alan ADF ve PP test istatistiği sonuçları düzeyler cinsinden ele alındığında değişkenlerin tablo değerleri \%1 anlamlılık düzeyinde Mac Kinnon kritik değerlerinden mutlak olarak küçük olduğu için Ho hipotezi reddedilemez ve serilerin durağan olmadığı sonucuna ulaşılır. Birinci farkları alınan serilerin test sonuçları değerlendirildiğinde $\mathrm{ADF}$ ve PP test istatistiği tablo değerleri \%1 anlamlılık düzeyinde Mac Kinnon kritik değerlerinden mutlak olarak büyük olduğu için Ho hipotezi reddedilir ve serilerin durağan olduğu kabul edilir.

ADF ve PP Birim kök testleri sonucunda değişkenlerin düzeyde durağan olmayıp birinci farkları alındığı zaman durağanlaştığı görülmektedir. Birinci dereceden farkları alınmış durağan serilerin grafikleri ise Şekil 2'de verilmiştir. 
Şekil 2: Farkları alınmış durağan konut fiyat endeksi, tüfe, reel efektif döviz kuru ve konut kredi faiz oranı serileri (2008-2014)

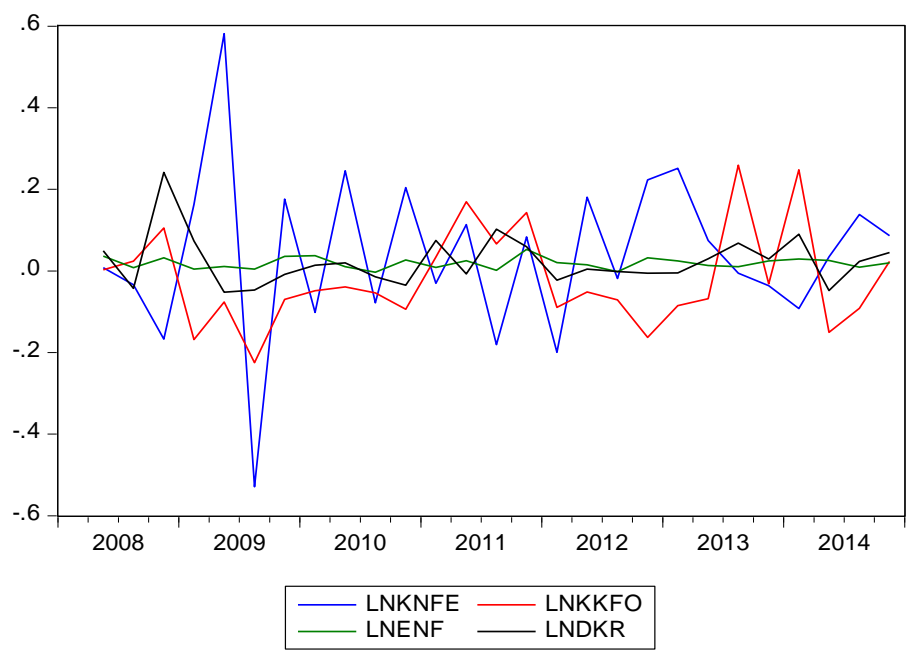

Konut fiyat endeksi, enflasyon ve reel efektif döviz kuru, konut kredi faiz oranı değişkenlerinin birinci farkları alındığında, durağan oldukları tespit edildikten sonra aralarındaki uzun dönemli ilişkiyi belirlemek amacıyla Johansen-Juselius eşbütünleşme testi uygulanacaktır. Johansen eş bütünleşme testi uygulanmadan önce değişkenlerin gecikme uzunluklarının tespit edilmesi gerekmektedir. VAR modelinde en uygun gecikme uzunluğunu belirlemek için kullanılan bazı testler şunlardır: Olabilirlik Oran Testi (LR), Son Tahmin Hatası (FPE), Akaike Bilgi Kriteri (AIC), Schwarz Bilgi Kriteri (SC) ve Hannan-Quinn Bilgi Kriteri (HQ).

Tablo 3. Gecikme uzunlukları

\begin{tabular}{ccccccc}
\hline Lag & LogL & LR & FPE & AIC & SC & HQ \\
\hline 0 & 91.92638 & NA & $7.73 \mathrm{e}-09$ & -7.327199 & -7.130856 & -7.275109 \\
1 & 177.4649 & $135.4360^{*}$ & $2.41 \mathrm{e}-11$ & -13.12208 & $-12.14036^{*}$ & -12.86163 \\
2 & 193.2898 & 19.78111 & $2.78 \mathrm{e}-11$ & $-13.10748^{*}$ & -11.34040 & -12.63868 \\
3 & 221.5158 & 25.87384 & $1.45 \mathrm{e}-11$ & -14.12632 & -11.57387 & -13.44915 \\
4 & 239.9157 & 10.73329 & $2.87 \mathrm{e}-11$ & -14.32631 & -10.98849 & -13.44079 \\
\hline
\end{tabular}

Not : * Illgili kritere göre uygun gecikme saylsını göstermektedir.

Tablodan kurulacak Johansen testi için seçilecek VAR modeli en uygun gecikme uzunluğu LR ve SC testleri yardımı ile bir olarak belirlenmiştir. Değişkenler arasında uzun dönemli ilişkinin varlığı Johansen eşbütünleşme yöntemi kullanılarak tahmin edilmiştir ve elde edilen eşbütünleşme testi sonuçları Tablo 4'te incelenmektedir. 
Tablo 4. Johansen Eşbütünleşme Testi Sonuçları

\begin{tabular}{ccccc}
\hline \multicolumn{5}{c}{$\lambda_{\text {iz İstatistiği }}$} \\
\hline Hipotezler & Özdeğer & İz & \% 5 Kritik Değer & Olas1lık \\
\hline Yok & 0.537495 & 55.52693 & 63.87610 & 0.2060 \\
En fazla 1 & 0.461900 & 35.47837 & 42.91525 & 0.2259 \\
En fazla 2 & 0.332829 & 19.36591 & 25.87211 & 0.2597 \\
\hline \multicolumn{5}{c}{$\lambda_{\text {maks İstatistiği }}$} \\
\hline Hipotezler & Özdeğer & Maks & \% 5 Kritik Değer & Olasilık \\
\hline Yok & 0.537495 & 20.04856 & 32.11832 & 0.6483 \\
En fazla 1 & 0.461900 & 16.11246 & 25.82321 & 0.5347 \\
En fazla 2 & 0.332829 & 10.52244 & 19.38704 & 0.5632 \\
\hline
\end{tabular}

Uygulanan eşbütünleşme testi sonuçlarına göre olasılık değerleri, \%5 anlamlılık düzeyinde kritik değerlerden küçük olduğundan dolayı eşbütünleşme vektörü bulunduğuna dair hipotez reddedilmiş̧ir. Dolayısıyla uzun dönemde değişkenler arasında bir ilişki olmadığı sonucuna ulaşılmıştır.

Değişkenler arasındaki nedensellik ilişkisi ve bu ilişkinin yönü Granger nedensellik testi vasıtası ile sınanmıştır. Test sonuçları Tablo 5'de gösterilmektedir.

Tablo 5. Granger Nedensellik Testi Sonuç Tablosu

\begin{tabular}{|c|c|c|c|}
\hline \multicolumn{4}{|c|}{ Bağımlı değişken: LNKNFE } \\
\hline & Ki-kare & sd & Olasılik \\
\hline LNKKFO & 5.112932 & 1 & 0.0237 \\
\hline LNDKR & 2.026421 & 1 & 0.0494 \\
\hline LNENF & 0.973690 & 1 & 0.0053 \\
\hline GENEL & 21.38032 & 3 & 0.0008 \\
\hline \multicolumn{4}{|c|}{ Bağımlı değişken: LNKKFO } \\
\hline & Ki-kare & sd & Olasilık \\
\hline LNKNFE & 0.454171 & 1 & 0.5004 \\
\hline LNDKR & 2.744699 & 1 & 0.0976 \\
\hline LNENF & 0.580605 & 1 & 0.4461 \\
\hline GENEL & 3.894912 & 3 & 0.2899 \\
\hline \multicolumn{4}{|c|}{ Bağımlı değişken: LNDKR } \\
\hline & Ki-kare & sd & Olasılik \\
\hline LNKNFE & 0.41810 & 1 & 0.0191 \\
\hline LNKKFO & 2.480526 & 1 & 0.0178 \\
\hline LNENF & 6.209211 & 1 & 0.7644 \\
\hline GENEL & 9.506087 & 3 & 0.0006 \\
\hline \multicolumn{4}{|c|}{ Bağımlı değişken: LNENF } \\
\hline & Ki-kare & sd & Olasılık \\
\hline LNKNFE & 0.232453 & 1 & 0.9668 \\
\hline LNKKFO & 0.054146 & 1 & 0.9096 \\
\hline LNDKR & 0.004090 & 1 & 0.9960 \\
\hline GENEL & 0.250648 & 3 & 0.9993 \\
\hline
\end{tabular}


Granger Nedensellik Testi bulgularına göre yüzde 5 anlamlılık düzeyinde konut fiyat endeksinden, konut kredi faiz oranına ve enflasyon oranına doğru tek yönlü bir nedensellik ilişkisinin bulunduğu görülmektedir. Bunun yanı sıra reel efektif döviz kurundan konut kredi faiz oranına doğru tek yönlü bir nedensellik ilişkisinin bulunduğu görülmektedir. Ayrıca konut fiyat endeksi ile reel efektif döviz kuru arasında çift yönlü bir nedensellik ilişkisine rastlanılmıştır.

Nedensellik testine ait bulgular çerçevesinde VAR modeli tahmin edilecektir. Çalışmada konut fiyat endeksi, enflasyon, reel efektif döviz kuru ve konut kredi faiz oranı değişkenleri arasındaki ilişkileri incelemek amacıyla VAR (Vektör Otoregresif Modeller) yönteminden yararlanılmıştır. VAR modeli ilk defa 1980 yılında Sims tarafından geliştirilen bir yöntemdir. Sims içsel ve dışsal değişken ayırımını kabul etmeyerek, bir ekonometrik modelde yer alan her değişkenin diğer bir değişkeni etkileyebileceğini söylemektedir. $\mathrm{Bu}$ değişkenlerin de diğer değişkenlerden etkilenebileceğini ileri süren Sims, VAR modelini geliştirmiştir (Sims, 1980: 1-49). Nedensellik testi sonrası elde edilen VAR modeli ise aşağıdaki tabloda görülmektedir.

Tablo 6. VAR Modeli

\begin{tabular}{ccccc}
\hline & D(LNKNFE) & D(LNKKFO) & D(LNENF) & D(LNDKR) \\
\hline $\mathrm{D}($ LNKNFE(-1)) & 0.717168 & -0.642714 & -0.006171 & 1.131048 \\
& $(0.17488)$ & $(1.12347)$ & $(0.14810)$ & $(0.48244)$ \\
& {$[4.10088]$} & {$[-0.57208]$} & {$[-0.04167]$} & {$[2.34446]$} \\
\hline $\mathrm{D}($ LNKKFO(-1)) & 0.035174 & 0.851486 & -0.002142 & 0.145625 \\
& $(0.02227)$ & $(0.14307)$ & $(0.01886)$ & $(0.06144)$ \\
& {$[1.57932]$} & {$[5.95135]$} & {$[-0.11357]$} & {$[2.37026]$} \\
\hline $\mathrm{D}($ LNENF(-1)) & 0.434041 & 1.153058 & 1.001210 & -0.128820 \\
& $(0.15583)$ & $(1.00104)$ & $(0.13196)$ & $(0.42987)$ \\
& {$[2.78543]$} & {$[1.15185]$} & {$[7.58730]$} & {$[-0.29967]$} \\
\hline $\mathrm{D}($ LNDKR(-1)) & -0.136854 & -0.564593 & -0.000293 & 0.153112 \\
& $(0.06965)$ & $(0.44743)$ & $(0.05898)$ & $(0.19213)$ \\
& {$[-1.96494]$} & {$[-1.26186]$} & {$[-0.00496]$} & {$[0.79691]$} \\
\hline $\mathrm{C}$ & -0.747854 & -1.931293 & 0.051560 & -5.349013 \\
& $(0.48542)$ & $(3.11839)$ & $(0.41107)$ & $(1.33909)$ \\
& {$[-1.54064]$} & {$[-0.61932]$} & {$[0.12543]$} & {$[-3.99451]$} \\
\hline $\mathrm{R}^{2}$ & 0.987429 & 0.787175 & 0.991363 & 0.921097 \\
F-istatistiği & 432.0012 & 20.34289 & 631.2626 & 64.20589 \\
\hline
\end{tabular}

Var modelinin yorumlanması tek başına bir anlam ifade etmediğinden dolayı, Etki-Tepki analizi ve Varyans ayrıştırması analizi yöntemlerine başvurulmaktadır ve bu yöntemlerin sonuçları ile ilgili yorumlamalar yapılmaktadır. Ancak model tahmin edildikten sonra hata terimine ait testlerin yapılması gerekmektedir. Ayrıca tahmin edilen modelin durağanlığı analiz edilmelidir. Modelin durağan olup olmadığının belirlenmesi katsayı matrisinin özdeğerlerine bağlıdır. Katsayı matrisinin özdeğerlerinin tümü birim çemberin içerisinde yer alıyor ise sistem durağandır ancak bir tanesi bile birim çemberin üzerinde veya dışarısında yer alırsa sistem durağan değildir. (Hendry ve Juselius, 2000: 10). 
Tablo 7. AR Karakteristik Polinomunun Ters Kökleri

\begin{tabular}{cc}
\hline Kök & Modulus \\
\hline 0.995464 & 0.995464 \\
$0.610895-0.064195 \mathrm{i}$ & 0.614259 \\
$0.610895+0.064195 \mathrm{i}$ & 0.614259 \\
0.175312 & 0.175312 \\
\hline
\end{tabular}

Tablo 7'de yer alan polinomun ters köklerine bakıldığında hepsi verilen referans aralıkları arasında yer almaktadır. Bu durum modelin durağanlık açısından bir sorun taşımadığını ifade eder. Bu durum AR Karakteristik Polinomunun Ters Kökleri birim çember analizi yardımıyla da kontrol edilerek destelenmiştir.

Şekil 3. AR Karakteristik Polinomunun Ters Kökleri

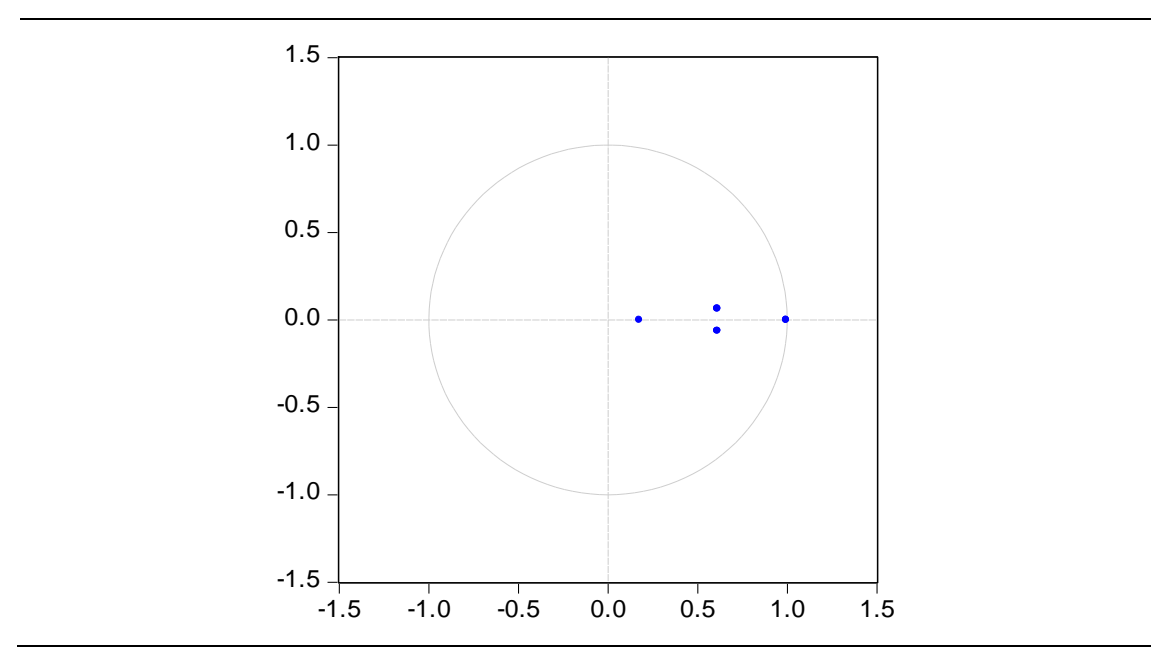

Şekil 3'de görüldüğü üzere AR Karakteristik Polinomunun Ters Köklerinin birim çemberin içerisinde yer alması ve çember dışında bulunmamasından dolayı kurulan VAR modeli istikrarlı bir yapı göstermektedir. VAR modelinin yapısal anlamda bir sorun içerip içermediğini tespit edebilmek için Otokorelasyon- LM ve White Değişen Varyans testleri de uygulanmıştır. Otokorelasyon testine ilişkin sonuçlar Tablo 8'de yer almaktadır.

$\mathrm{H}_{0}$ : Otokorelasyon yoktur.

$\mathrm{H}_{1}$ : Otokorelasyon vardır.

Tablo 8. Otokorelasyon-LM Testi Sonuçları

\begin{tabular}{ccc}
\hline Gecikme & LM istatistiğ $\mathrm{i}$ & Olasılık \\
\hline 1 & 18.20195 & 0.3122 \\
2 & 13.21923 & 0.6567 \\
3 & 20.51628 & 0.1979
\end{tabular}




\begin{tabular}{ccc}
4 & 16.21184 & 0.4383 \\
5 & 7.452164 & 0.9635 \\
6 & 17.77556 & 0.3372 \\
7 & 8.926756 & 0.9164 \\
8 & 9.037968 & 0.9118 \\
9 & 17.77478 & 0.3372 \\
10 & 18.88549 & 0.2746 \\
11 & 9.354570 & 0.8981 \\
12 & 9.965925 & 0.8684 \\
\hline
\end{tabular}

H1:otokorelasyon vardır boş hipotezinin kabul edilmemesinden dolayı modelde otokorelasyon sorunu olmadığı sonucu ortaya çıkmaktadır. VAR modelindeki hata terimleri arasında otokorelasyon ile karşılaşılmadığını doğrulamak için uygulanan LM testi sonuçlarına göre, ele alınan 12 gecikme düzeyinde de otokorelasyon bulunmamaktadır. Hata terimlerinin varyansının bütün örneklem için sabit olup olmadığını tespit edebilmek amacıyla yapılan White Değişen Varyans Testi sonuçları ise Tablo 9'da gösterilmektedir.

Tablo 9. White Testi

\begin{tabular}{ccc}
\hline Joint test & & \\
\hline Ki Kare & Serbestlik Derecesi & Olas1lik \\
\hline 91.64855 & 80 & 0.1757 \\
\hline
\end{tabular}

Ki-Kare değeri tahmin edilen modelde değişen varyans sorunu olmadığını başka bir ifadeyle hata teriminin varyansının tüm gözlemler için aynı olduğunu ortaya koymaktadir.

Tablo 10. Normal Dağılım Testi Sonuçları

\begin{tabular}{cccc}
\hline Bileşen & Jarque-Bera & df & Olas1lik \\
\hline 1 & 0.680373 & 2 & 0.7116 \\
2 & 3.518638 & 2 & 0.1722 \\
3 & 0.659120 & 2 & 0.7192 \\
4 & 0.640924 & 2 & 0.7258 \\
Joint & 5.499054 & 8 & 0.7031 \\
\hline
\end{tabular}

Jargue-Bera istatistiği ile modeldeki değişkenlerin bir bütün olarak normal dağılıma sahip olduğu boş hipotezi reddedilemediğinden değişkenlerin normal dağılımlı olduğu sonucuna ulaşılmıştır.

Bir makroekonomik büyüklüğün üzerinde etkili olan değişkenin belirlenmesi varyans ayrıştırması ile sağlanmaktadır. Ayrıca etkili bulunan bu değişkenin politika aracı olarak kullanılabilirliği ise etki-tepki fonksiyonları ile saptanmaktadır (Özgen ve Güloğlu, 2004: 97). Başka bir deyişle etki-tepki analizi bir değişkende oluşacak olan rastgele bir şokun sistemdeki diğer değişkenler üzerindeki etkisini açıklamaktadır. Bu nedenler ekonomik politikaların yönünü tayin etmede önemli bir görev aracı olmaktadır. Etki-tepki fonksiyonu, rastgele ele alınan bir değişkende oluşan bir standart hatalık şoka karşı bağımlı değişkenin 
tepkisinin ölçmektedir. Etki tepki fonksiyonları bahse konu olan şokun, içsel değişkenlerin şimdiki ve gelecekteki değerine olan etkisi görülen fonksiyonlardır. Varyans ayrıştırması değişkenlerin kendilerinde ve diğer değişkenlerde görülen şokların kaynaklarını yüzdesel olarak açıklayarak, değişkenlerde meydana gelen bir değişimin yüzde kaçının kendisinden, yüzde kaçının diğer değişkenlerden dolayı oluştuğu hakkında bilgi vermektedir (Taş ve Uysal, 2013: 44-63).

\section{Şekil 4. Etki-Tepki Grafikleri}
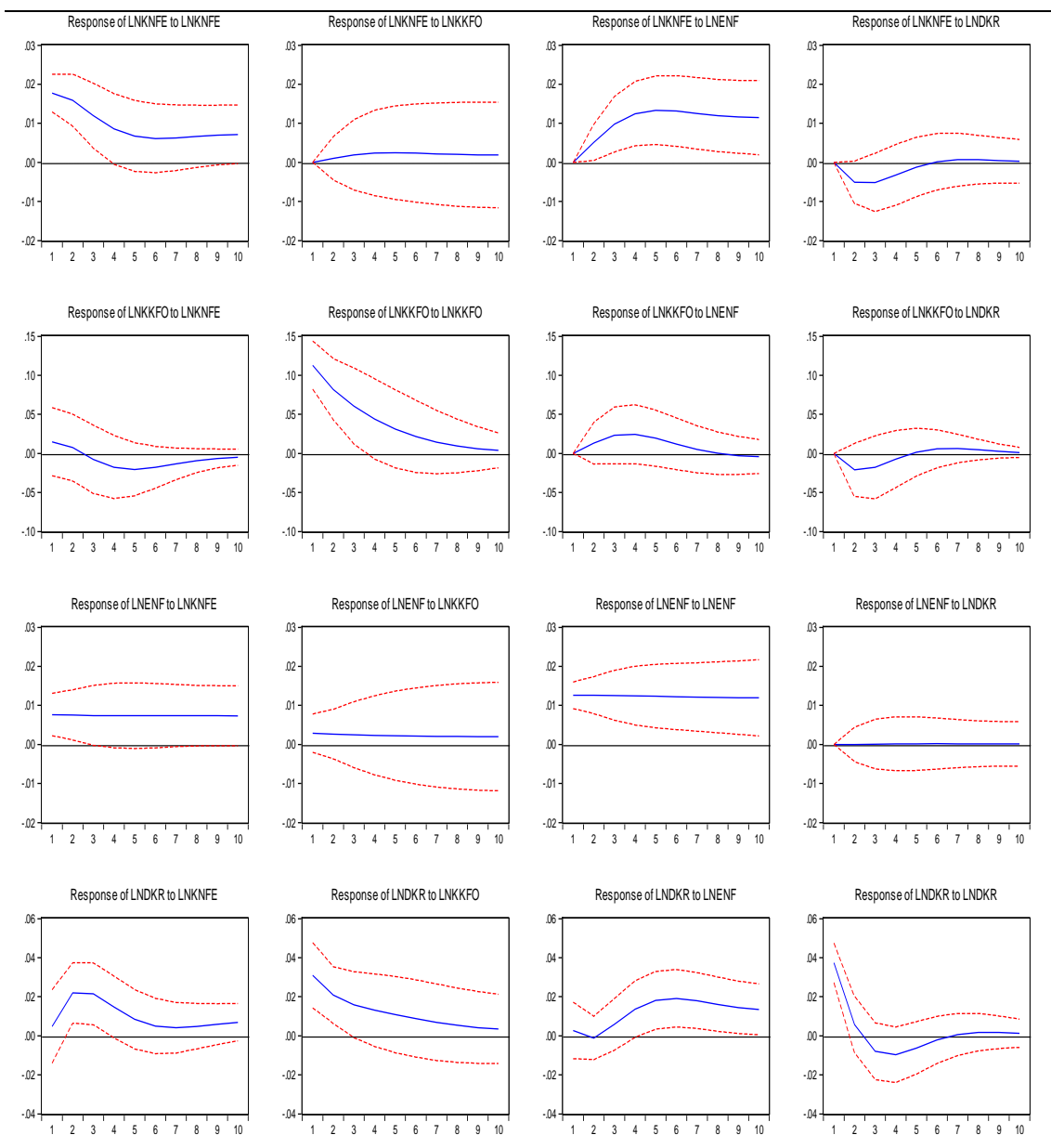

Şekil 4'de her değişkenin birbirine ve diğer tüm değişkenlere uygulanan bir birim şok karşısındaki tepkileri ölçülmeye çalışılmıştır. Buna göre şekilden de görülebileceği üzere, Konut fiyat endeksi değişkeninde meydana gelen bir standart sapmalık şokun en değerli etkisi tahmin edilebileceği üzere kendisi üzerinde gerçekleşmektedir. Konut kredi faiz oranları ise en büyük tepkiyi kendisinde ve reel efektif döviz kurunda meydana gelen değişikliklere vermektedir. Reel efektif 
döviz kuru ise en büyük tepkiyi ise kendisine vermektedir. Konut fiyat endeksi ve reel efektif döviz kuru ise enflasyon oranları üzerinde aynı yönlü etki oluşturmaktadırlar. Bu açıdan bakıldığında Konut fiyat endeksini açıklamada en büyük etki reel efektif kuru döviz olurken 2. olarak konut faiz oranları son olarak enflasyon oranları şeklinde sıralanmaktadır.

Serilerdeki değişimin nedenlerini belirlemek amacı ile uygulanan yöntemlerden bir diğeri de Varyans ayrıştırmasıdır. VAR modelinin hareketli ortalamalar bölümünden elde edilen varyans ayrıştırması, değişkenlerin kendilerinde ve diğer değişkenlerde oluşan şokların kaynaklarını yüzdesel bir biçimde açıklamaktadır. Varyans ayrıştırması analizi, ele alınan değişkenlerde görülecek olan bir değişimin yüzde kaçının kendisinden, yüzde kaçının diğer değişkenlerden dolayı meydana geldiğinin ifade etmektedir. Ayrıca değişkenler arasındaki nedensellik ilişkilerinin boyutları hakkında da açıklayıcı bir nitelik taşımaktadır (Enders, 1995: 310-312).

Tablo 11. Varyans Ayrıştırması

LNKNFE Değişkeni İçin Varyans Ayrıştırması Sonuçları

\begin{tabular}{cccccc}
\hline Dönem & S.E. & LNKNFE & LNKKFO & LNENF & LNDKR \\
\hline 1 & 0.017726 & 100.0000 & 0.000000 & 0.000000 & 0.000000 \\
2 & 0.024908 & 91.42858 & 0.157171 & 4.185855 & 4.228397 \\
3 & 0.029804 & 79.86579 & 0.513662 & 13.61715 & 6.003390 \\
4 & 0.033656 & 69.10166 & 0.903060 & 24.35902 & 5.636255 \\
5 & 0.036916 & 60.72437 & 1.202175 & 33.28425 & 4.789197 \\
6 & 0.039724 & 54.81509 & 1.391846 & 39.65593 & 4.137131 \\
7 & 0.042183 & 50.81945 & 1.501498 & 43.98556 & 3.693494 \\
8 & 0.044402 & 48.10982 & 1.563447 & 46.96974 & 3.356989 \\
9 & 0.046467 & 46.18225 & 1.600087 & 49.14159 & 3.076065 \\
10 & 0.048427 & 44.69794 & 1.624528 & 50.84231 & 2.835229 \\
\hline
\end{tabular}

LNKKFO Değişkeni İçin Varyans Ayrıştırması Sonuçları

\begin{tabular}{cccccc}
\hline Dönem & S.E. & LNKNFE & LNKKFO & LNENF & LNDKR \\
\hline 1 & 0.113873 & 1.693719 & 98.30628 & 0.000000 & 0.000000 \\
2 & 0.142679 & 1.346025 & 95.63072 & 0.830068 & 2.193192 \\
3 & 0.157875 & 1.335184 & 92.77975 & 2.801362 & 3.083701 \\
4 & 0.166863 & 2.329077 & 90.05277 & 4.663630 & 2.954525 \\
5 & 0.172130 & 3.601195 & 87.94620 & 5.668731 & 2.783877 \\
6 & 0.174915 & 4.546262 & 86.68555 & 5.964031 & 2.804162 \\
7 & 0.176212 & 5.072423 & 86.07828 & 5.961603 & 2.887692 \\
8 & 0.176772 & 5.324022 & 85.81166 & 5.923960 & 2.940356 \\
9 & 0.177035 & 5.443728 & 85.66988 & 5.930284 & 2.956107 \\
10 & 0.177197 & 5.510860 & 85.55897 & 5.974484 & 2.955683 \\
\hline
\end{tabular}

LNENF Değişkeni İçin Varyans Ayrıştırması Sonuçları

\begin{tabular}{llllll}
\hline Dönem & S.E. & LNKNFE & LNKKFO & LNENF & LNDKR \\
\hline
\end{tabular}




\begin{tabular}{cccccc}
\hline 1 & 0.015011 & 25.97509 & 3.730683 & 70.29423 & 0.000000 \\
2 & 0.021157 & 25.69943 & 3.449115 & 70.85143 & $2.68 \mathrm{E}-05$ \\
3 & 0.025811 & 25.49969 & 3.231213 & 71.26846 & 0.000637 \\
4 & 0.029680 & 25.41905 & 3.056977 & 71.52135 & 0.002618 \\
5 & 0.033047 & 25.43925 & 2.914856 & 71.64094 & 0.004948 \\
6 & 0.036058 & 25.52249 & 2.797645 & 71.67315 & 0.006709 \\
7 & 0.038804 & 25.63355 & 2.700366 & 71.65837 & 0.007711 \\
8 & 0.041343 & 25.74817 & 2.619240 & 71.62444 & 0.008154 \\
9 & 0.043713 & 25.85348 & 2.551233 & 71.58700 & 0.008289 \\
10 & 0.045942 & 25.94491 & 2.493857 & 71.55294 & 0.008289 \\
\hline
\end{tabular}

LNDKR Değişkeni İçin Varyans Ayrıştırması Sonuçları

\begin{tabular}{cccccc}
\hline Dönem & S.E. & LNKNFE & LNKKFO & LNENF & LNDKR \\
\hline 1 & 0.048899 & 0.937151 & 40.18571 & 0.300100 & 58.57704 \\
2 & 0.057795 & 15.08973 & 41.73672 & 0.258734 & 42.91482 \\
3 & 0.064432 & 23.23057 & 39.67053 & 1.032009 & 36.06689 \\
4 & 0.069423 & 24.49670 & 37.71400 & 4.755953 & 33.03334 \\
5 & 0.073315 & 23.27787 & 35.99521 & 10.38162 & 30.34530 \\
6 & 0.076455 & 21.82128 & 34.40748 & 15.79091 & 27.98032 \\
7 & 0.078942 & 20.73830 & 33.03154 & 19.97898 & 26.25118 \\
8 & 0.080905 & 20.09557 & 31.88407 & 22.98189 & 25.03847 \\
9 & 0.082530 & 19.82976 & 30.90083 & 25.16468 & 24.10473 \\
10 & 0.083977 & 19.82810 & 30.01276 & 26.85773 & 23.30140 \\
\hline
\end{tabular}

Serilerdeki meydana gelen değişimin nedenlerini tespit etmek amacı ile başvurulan yöntemlerden olan Varyans ayrıştırması sonuçları Tablo 11'de yer almaktadır. Tablo 11'deki Konut fiyat endeksi değişkeni için varyans ayrıştırması sonuçlarına göre 10. dönemin sonunda Konut fiyat endeksine ait öngörü hata varyansının \%50,84'ünün enflasyon oran1, \%2,83’ünün reel efektif döviz kuru ve \%1,62'sinin konut kredi faiz oranı tarafından belirlendiği şeklinde yorumlanabilir. Yaklaşık \%44,68'lik kısmı ise konut fiyat endeksinin kendisi tarafından açıklanmaktadır. Konut kredi faiz oranı değişkeni için varyans ayrıştırması sonucuna göre 10. dönemin sonunda konut kredi faiz oranı hata varyansının $\% 5,97$ 'si enflasyon oran1, \%5,51'i konut fiyat endeksi ve $\% 2,95$ 'i reel efektif döviz kuru tarafından açıklanmaktadır. Yaklaşık \% $85,5^{\prime}$ 'lik kısmı ise konut kredi faiz oranının kendisi tarafından açıklanmaktadır. Enflasyon oranı için bulunan varyans ayrıştırması sonucu ise \%25,94'ü konut fiyat endeksi, \%2,49'u konut kredi faiz oranı, \%0,008'i reel efektif reel efektif döviz kuru ve \%71,55'i enflasyon oranının kendisi tarafından açıklanmaktadır. Reel efektif döviz kuru için bulunan varyans ayrıştırması sonucu ise \%19,8 inin konut fiyat endeksi, \%26,8'inin enflasyon oran1, \%30'unun konut kredi faiz oran1 ve \%23,30'unun reel efektif döviz kuru tarafından açıklandığını göstermektedir. 


\section{SONUÇ}

ABD'de 2008 yılında, konut piyasalarında yaşanan sorunlardan dolayı ortaya çıkan finansal kriz, $\mathrm{ABD}$ ve $\mathrm{AB}$ ülkelerini ekonomik açıdan derinden etkilemiştir. 2008 finansal krizi, Çin, Hindistan, Rusya, Türkiye gibi ülkeleri ekonomik açıdan zorlamış olsa da, 2009 sonrası dönemde bu ülkeler çok hızlı bir şekilde toparlanma göstererek diğer ülkeler ile kıyasladığımızda üretim ve büyümede artış göstermiştir. Özellikle Türkiye'deki konut sektörünün ABD'deki konut sektörü kadar finansal krizden etkilenmemesinin sebebi türev piyasaların ve konut piyasalarının ABD'deki kadar gelişmiş olmamasıdır.

Bu çalışmada, 2008-2014 yılları arası konu fiyat endeksi, konut kredi faiz oranı, reel efektif döviz kuru ve enflasyon oranları çeyreklik verileri kullanılarak, değişkenler arasındaki ilişkiyi saptamak amacıyla gerekli ekonometrik analizler yapılmıştır. Yapılan analizlerde değişkenleri arasında uzun dönemli bir ilişkiye rastlanılmamıştır. Ayrıca değişkenler arasındaki nedensellik ilişkisini belirlemek amaciyla Granger nedensellik testi uygulanmıştır. Bunun sonucunda, konut fiyat endeksinden enflasyon oranı ve konut kredi faiz oranına doğru tek yönlü bir ilişki saptanmıştır. Reel efektif döviz kurundan konut kredi faiz oranına ve konut fiyat endeksine doğru da tek yönlü bir nedensellik ilişkisinin bulunduğu görülmektedir. Ayrıca konut fiyat endeksi ile reel efektif döviz kuru arasında çift yönlü bir nedensellik ilişkisine rastlanılmıştır.

Analizler sonucu elde edilen bulgulara göre finansal kriz ve sonrası dönemde Türkiye'de konut fiyatlarının artışı veya azalışında makroekonomik değişkenlerin etkisinin olduğu görülmektedir. Faiz oranları, enflasyon ve özellikle döviz kurunda meydana gelecek değişmeler, konut fiyatlarında yaşanacak artış veya azalışlarda belirleyici bir etken olmaktadırlar. Bu durum konut talebine olan artışı dolayısı ile de inşaat sektörünün gelişmesini büyük ölçüde etkileyecektir. İnşaat sektörünün gelişmesi ile istihdam alanı yaratılacak ve büyümenin önemli kalemlerinden olan inşaat sektöründeki artış ekonomik büyümeyi de olumlu yönde etkileyecektir.

Ulusal ve uluslararası çalışmalarda ulaşılan sonuç; konut fiyatlarını etkileyen değişkenler üzerinde bir görüş birliği olmamasıdır. Çalışmada daha önce yapılan çalışmalara benzer sonuçlara ulaşılmaktadır. Elde edilen bulguların mevcut literatüre olan uyumu değerlendirildiğinde çalışma, Öztürk ve Fitöz (2009), Adams ve Füss (2010) ve Agnello ve Schuknecht (2011) ve Çankaya (2013)'nın bulguları ile benzer sonuçlar taşıdığı gözlenmiş̧ir.

\section{KAYNAKÇA}

Adams, Z., \& Füss, R. (2010). Macroeconomic determinants of international housing markets. Journal of Housing Economics, 19(1), 38-50. doi:10.1016/j.jhe.2009.10.005 
Adrian, C., \& Darnell, A. (1990). Dictionary of Econometrics. England: Edward Elgar Pub.

Agnello, L., \& Schuknecht, L. (2011). Booms and busts in housing markets: determinants and implications. Journal of Housing Economics, 20(3), 171190. doi:10.1016/j.jhe.2011.04.001

Badurlar, İ. Ö. (2008). Türkiye'de Konut Fiyatları ile Makro Ekonomik Değişkenler Arasındaki İlişkinin Araştırılması. Anadolu Üniversitesi Sosyal Bilimler Dergisi, 8(1), 223-238.

Baldemir, E., Kebiç, Y., \& İnci, M. (2008). Estimating Hedonic Demand Parameters in Real Estate Market: The Case of Muğla. Muğla Üniversitesi Sosyal Bilimler Enstitüsü Dergisi, 20(1), 41-66.

Beltratti, A., \& Morana, C. (2010). International house prices and macroeconomic fluctuations. Journal of Banking \& Finance, 34(3), 533-545. doi:10.1016/j.jbankfin.2009.08.020

Cohen, J. P., \& Coughlin, C. C. (2008). Spatial hedonic models of airport noise, proximity, and housing prices. Journal of Regional Science, 48(5), 859-878. doi: 10.1111/j.1467-9787.2008.00569.x

Çankaya, S. (2013). Konut Fiyatları ve Makroekonomik Faktörler Arası İlişkiye Global Bakış. Maliye Finans Yazıları, 27(100), 143-154.

Enders, W. (2008). Applied econometric time series. New York: John Wiley \& Sons Inc.

Granger, C. W., \& Newbold, P. (1974). Spurious regressions in econometrics. Journal of Econometrics, 2(2), 111-120.

Gujarati, D. N. (1995). Basic econometrics, 3rd. USA: Mc Graw-Hills Int eds.

Hendry, D. F., \& Juselius, K. (2000). Explaining cointegration analysis: Part 1. The Energy Journal, 21(1), 1-42.

Karg1, B. (2013). Housing market and economic growth relation: time series analysis over Turkey (2000-2012). International Journal of Human Sciences, 10(1), 897-924.

Kearney, C., \& Monadjemi, M. (1990). Fiscal policy and current account performance: International evidence on the twin deficits. Journal of Macroeconomics, 12(2), 197-219. doi:10.1016/0164-0704(90)90029-A

Keating, J. W. (1990). Identifying VAR models under rational expectations. Journal of Monetary Economics, 25(3), 453-476. doi:10.1016/03043932(90)90063-A

Kumar, V., Leone, R. P., \& Gaskins, J. N. (1995). Aggregate and disaggregate sector forecasting using consumer confidence measures. International Journal of Forecasting, 11(3), 361-377. doi:10.1016/0169-2070(95)00594-2 
Lebe, F., \& Akbaş, Y. E. (2014). Türkiye'nin Konut Talebinin Analizi: 19702011. Atatürk Üniversitesi İktisadi ve İdari Bilimler Dergisi, 28(1), 57-83.

Özgen F. B. \& Güloğlu B. (2004). Türkiye'de iç borçların iktisadi etkilerinin VAR tekniğiyle analizi. ODTÜ Gelişme Dergisi, 31(1), 93-114.

Öztürk, N., \& Fitöz, E. (2012). Türkiye'de Konut Piyasasının Belirleyicileri: Ampirik Bir Uygulama. Uluslararası Yönetim İktisat ve İşletme Dergisi, 5(10), 21-46.

Pınar, A., \& Demir, M. (2014). Konut Sektöründe Kapitalizasyon Oranlarını Belirleyen Faktörler: Türkiye İçin Bir Mikro Veri Analizi. Sosyoekonomi, 22(22), 385-398. doi:10.17233/se.93073

Sims, C. A. (1980). Macroeconomics and reality. Econometrica: Journal of the Econometric Society, 48(1), 1-48. doi:10.2307/1912017

Taş. T., \& Uysal, D. (2013). Reel Döviz Kuru Sapması: Türkiye Örneği. Aksaray Üniversitesi İktisadi ve İdari Bilimler Fakültesi Dergisi, 5(1), 41-63.

Tatlı, H. (2013). Konut Sahipliğinin Belirleyicileri: Hanehalkı Reisleri Üzerine Bir Uygulama. Akademik Yaklaşımlar Dergisi, 4(2), 40-63.

Tiwari, P., Parikh, K., \& Parikh, J. (1999). Effective housing demand in Mumbai (Bombay) metropolitan region. Urban Studies, 36(10), 1783-1809. doi:10.1080/0042098992827

Tsatsaronis, K., \& Zhu, H. (2004). What drives housing price dynamics: crosscountry evidence. BIS Quarterly Review, 65-78

Uğur, L.O., \& Sivri, A.R. (2014). Toplu Konut Projelerinde Maliyetlerin Regresyon Metodu ile İncelenmesi. Düzce Üniversitesi Bilim ve Teknoloji Dergisi, 2(1), 251-270.

Üçdoğruk, Ş. (2001). İzmir İlinde Emlak Fiyatlarına Etki Eden Faktörler-Hedonik Yaklaşım. Dokuz Eylül Üniversitesi İktisadi ve Idari Bilimler Fakültesi Dergisi, 16(2), 149-161.

Wen, H. Z., Jia, S. H., \& Guo, X. Y. (2005). Hedonic price analysis of urban housing: An empirical research on Hangzhou, China. Journal of Zhejiang University(Science), 6(8), 907-914.

Yang, Z. (2001). An application of the hedonic price model with uncertain attribute-the case of the People's Republic of China. Property Management, 19(1), 50-63. doi:10.1108/02637470110366202

Yankaya, U., \& Çelik, M. (2005). İzmir Metrosunun Konut Fiyatları Üzerindeki Etkilerinin Hedonik Fiyat Yöntemi İle Modellenmesi. Dokuz Eylül Üniversitesi İktisadi ve İdari Bilimler Fakültesi Dergisi, 20(2), 61-79. 
